\title{
智慧城市的测绘地理信息服务模式分析
}

林韬略

广西北斗星测绘科技有限公司

DOI:10.32629/btr.v2i7.2354

[摘 要] 近年来,随着我们国家的测绘地理信息在整个城市建设中的广泛应用,我们将测绘地理技术不断地应用到城市建设 中,以社会经济产业的加速发展来完善智慧城市建设的重要途径。在智慧城市建设中,构建城市基础地理信息平台,建立准确、 动态、高效的共享型数据平台,全面实现空间数据共享, 实现由传统地图制图向综合地理信息服务转变,是城市可持续发展、信 息化管理的迫切需要。测绘地理信息技术所发挥的作用就是不同忽视的,对于相应的服务模式进行研究非常必要。本文针对 面向智慧城市的测绘地理信息服务模式进行探究。

[关键词] 智慧城市; 测绘地理信息服务; 模式

\section{1 相关概述}

1. 1 地理信息系统

地理信息系统 (GIS技术), 它是诞生于计算机网络技术 基础上的一种测绘信息技术, 通过计算机相关软件的应用, 可以很好地完成地理数据信息进行采集、处理和存储工作, 同时它还可以对数据信息进行可视化分析, 为城市建设和管 理的决策提供有力的指导。另外, 地理信息系统的应用可以 帮助工作人员建立三维模型和数据库, 这样不仅极大地提高 了信息处理和分析效率, 而且极大地降低了人工劳动。现阶 段, GIS的应用十分广泛, 在工程测量、城市规划测量中都起 到重要的作用。而对于智慧城市而言, 它是智慧化城市的升 级和革新, 所以其对于信息化和智慧化的管理要求严格, 通 过地理信息系统的应用, 需要在原有基础上搭建时空信息云 平台, 这样才能满足智慧城市的建设需求。

\section{2 智慧城市的概念}

智慧城市就是在城市建设时应用信息技术, 从科学的角 度出发, 应用智能技术满足城市发展的需求, 以此来提高城 市居民生活的质量。城市建设要以以人为本为原则, 这是城 市智能化建设的关键。打造智慧城市的基础条件是在应用信 息技术的过程中对信息技术合理运用。从国外的智慧城市建 设情况来看, 如韩国的仁川市、新加坡等都着力于打造智慧 城市, 而且落实到政策的层面, 达到智慧城市建设的目的。以 新加坡为例, 在城市建设中以智慧城市的建设为目的, 包括 通信技术、电子商务达到都在不断地发展着, 将电子政府服 务窗口建立起来, 接受市民的咨询和监督, 应用信息通信技 术将城市的智慧化建设带动起来。随着政府服务质量的提高, 城市智慧化的层次也会相应地提高。

\section{2 智慧城市建设中测绘地理信息服务的内在含义}

智慧城市的建设中, 要实现各项目标, 就要对地理信息 进行测绘, 包括测绘地理信息服务的质量以及服务水平都与 城市的智慧化建设密切相关。要完成建设目标, 获得良好的 城市建设质量, 使得智慧技术切实地发挥其可利用价值, 就 要对目前的测绘地理信息服务进行分析, 确保智慧城市稳定
运行。此外, 还要将物联网技术充分利用起来, 综合数字城市 的各项指标, 对城市的人与物的变化详细分析, 将云计算技 术充分利用起来, 分析城市发展中的动态变化情况, 包括人 力、时间以及资金带动, 采用有效的成本控制策略, 使得城市 向智能化方向发展。

\section{3 智慧城市对测绘地理信息服务的本质要求}

智慧城市若将城市视为生命体, 就要为该生命体的延续 与发展做努力。智慧城市为新时期经济层面的重要课题, 是 城市人口增加, 土地、淡水及能源资源短缺等矛盾尖锐背景 下的产物。测绘地理信息服务的本质要求是帮助城市解决影 响可持续发展的问题, 推动城市更科学、更快地发展, 以此改 善和提高城市居民的生活质量。从解决问题角度分析, 能源 消耗、时间成本及环境污染等形成了智慧城市的评价标准。 换言之, 要以最少能源消耗、环境污染、最少时间及人力成 本等来处理所有问题。在标准下, 需要适时调整测绘地理信 息服务的基本内容和方式, 充分考虑城市发展中的 “事件” 需求, 找寻以地理空间分布为基础的事件解决方法, 促进地 理信息数据服务方式的全新升级, 以加快智慧服务的延展。 例如, 国内不少大城市交通状况较为拥堵, 基于测绘地理信 息层面, 怎样在当前道路条件下, 利用地理信息技术及资源 优势, 来减轻城市交通拥堵压力; 针对地理信息数据的探索 方式, 应升级以网络云端服务器与客户端嵌入式设备为基础 的调用模式, 帮助用户减少时间与经济成本。

\section{4 面向智慧城市的测绘地理信息服务模式}

4. 1借助测绘地理信息技术打造三维模型

智慧城市时空信息云平台建设的重要关键是精细化的 三维模型和全景影像, 也是智慧城市建设发展的基础和框 架。打造智慧城市三维建模需要应用多种技术, 智慧城市云 平台建设要通过丰富的地理信息数据和全景影像、云系统平 台为其提供支持。在智慧城市发展建设中人们常用的测量方 式是低空无人机。低空无人机从发展应用情况来看主要是指 在低空利用摄像机来拍摄整个城市发展画面, 并借助测绘地 理信息技术来分析拍摄出来的照片。测绘地理信息技术在应 
用的过程中能够提升拍摄机器的拍摄精确性、分辨性, 表现 在应用低空无人机打造城市发展建设三维模型。在三维模型 打造之后需要测绘人员加强对整个三维模型的应用分析, 借 助拍摄完成的照片打造三维立体空间, 借助三维立体空间的 可视化功能来方便人们对地理信息的查看和使用。

4.2 从智慧城市发展的角度出发构建型测绘地理信息服 务模式的条件

从智慧城市发展的角度出发构建型测绘地理信息服务 模式, 需要具备的条件是将测绘地理信息网构建起来, 及时 准确地获得地理信息数据, 提高数据信息的精密度, 使得数 据信息具有更为广泛的用途。将云计算技术充分利用起来, 使得处理数据信息的质量和效率都有所提升, 构建起先进的 商务模式, 地理信息的质量有所提升, 智慧城市建设的速度 也不断加快。对地理信息充分利用, 而且根据智慧城市建设 需要予以完善, 还要深层次地挖掘有价值的地理数据信息, 使得信息的价值得以充分发挥。

4. 3测绘地理信息为智慧城市建设提供智能化决策

智慧城市建设过程中, 测绘地理信息所提供的位置服 务、空间信息服务以及智能服务系统是城市运行的基础。通 过地理信息平台对信息的获取、处理、管理以及决策等信息 的统一处理, 使得智慧城市可以获取智能化的空间服务。在 智慧城市建设中通过测绘地理信息技术的运用, 让智慧城市 的各方面资源得到了最大限度的利用, 使得城市信息资源更 加精准与高效, 为智慧城市建设提供智能化决策服务。通过 对城市建设中各类传感器所收集的信息检测、监督与实时分 析, 并经过大数据的处理来整合资源, 提供强力的决策支持, 让智慧城市建设变得科学, 促进智慧城市智能化建设。

\section{4 低空摄影测量系统}

低空无人机是当前常用的一种测量工具系统, 它是由人 为的控制在低空利用一些摄像机进行拍摄的这样一个过程。 因此, 在实际应用时, 研究人员需要直接使用低空摄影测量 系统来测量城市的整体空间格局, 并保证拍摄的质量符合国 家相关标准, 才能够拍摄出准确的数据信息。因此, 在进行实 际摄影工作时, 工作人员需要具备很强的三维空间感, 通过 了解城市的地理信息, 能够对城市的三维模型进行建设。另
外, 工作人员还需要利用可视化技术来显示城市地理信息, 这样有利于智慧城市的建设。

4. 5 测绘地理信息服务模式的支撑条件

第一, 能获取精度高、用途广的地理信息数据为基础。 智慧城市背景下, 应尽快完善测绘地理信息传感网, 提升获 取地理信息数据的能力。对于 “事件” 汼引为核心的地理信 息服务要求, 应妥善解决全天候、高分辨率的对地观技术等 难点, 为数据处理及知识挖掘奠定基础。第二, 智慧城市背景 下, 应强化地理信息数据技术创新, 深入挖掘地理信息数据 及知识, 研发以地理信息空间为基础的知识挖掘系统。该技 术为构建新型测绘地理信息服务模式的支撑技术, 可为测绘 地理信息智慧应用方案提供可靠保障。第三, 基于智慧城市 需求, 重点应提升地理信息数据的智能处理能力, 以便在短 时间、低成本情况下解决好各类信息。首先应发展云GIS处 理技术, 促进数据处理效率提升。现阶段, ESRI、超图等公司 在该领域已形成较完善的商业模式; 其次应处理遥感影像自 动解译等一些技术难题, 尽管国内学者已不断突破该技术领 域, 但短期内卫星遥感影像解译还无法实现全自动, 原因在 于地物受时间、气候及环境等多因素影响, 自动识别难度大。

\section{5 结语}

综上所述, 构建全新的测绘地理信息服务模式, 不仅是 时代的发展需求, 更是实现测绘地理信息事业持续稳定发展 的内在需要。为了保证测绘地理信息服务质量, 就需要对城 市的发展情况全面了解, 重点掌握城市运行中的影响因素。 智慧城市管理中, 测绘地理信息服务要切实地发挥作用, 就 要将新型的服务模式制定出来, 切实提高智慧城市的建设水 平, 推动现代化建设的快速发展。

\section{[参考文献]}

[1]张建芳.面向智慧城市的测绘地理信息服务分析与 研究 [J].城市地理,2016,(16):52-53.

[2]赵峰.面向智慧城市的上海测绘地理信息服务对策思 考[J].上海国土资源,2017,38(1):93-95.

[3]毛建华.面向智慧城市的测绘地理信息服务模式 [J]. 建材与装饰,2015,(50):175-176. 